\title{
The Role of Science as a Factor of Integration of Countries in the Context of Globalization
}

\author{
Vera Afanasievna Stolyarova ${ }^{1}$, Sergey Vasilievich Kupriyanov ${ }^{1}$, Zlata Vladislavovna Stolyarova ${ }^{1}$, Heidi \\ Francklin Damiao Saldanha ${ }^{1} \&$ Rovin Adrian Sukhraj ${ }^{1}$ \\ ${ }^{1}$ Belgorod State Technological University named after V. G. Shukhov, Russia \\ Correspondence: Vera Afanasievna Stolyarova, Belgorod State Technological University named after V. G. \\ Shukhov, Kostyukov Street, 46, 308012, Belgorod, Russia.
}

Received: November 11, 2014

Accepted: December 23, 2014 Online Published: March 16, 2015

doi:10.5539/ass.v11n7p278

URL: http://dx.doi.org/10.5539/ass.v11n7p278

\begin{abstract}
Geopolitical situation in the world today is resigned to the active influence of globalization processes. In turn, they can develop in opposite directions. On the one hand it implies the openness of economies, the fusion of cultural and social spheres, on the other hand it demonstrates the localization of the competitive advantages of independent states. This localization is caused by uneven distribution of economic resources in a wide range of factors: natural, physical, geographical, social, historical, ethnic and others. Consequently, diversification of economic structure of countries on a number of ranking prejudge their macroeconomic indicators that forms the current multi-level system.
\end{abstract}

Keywords: scientific research, globalization, international competitiveness, transnational corporation

\section{Introduction}

Most experts in the field of macro-analysis (Vechkanov, 2005; Chizhova, 2004; Cupriyanov, 2008; Rudychev, 1998) consider the geopolitical system, dividing countries into three groups: low income, middle level and high level. Based on this principle, it is possible to distinguish three groups of countries: industrialized countries with developed market economy; developing countries in Asia, Africa, Latin America, Oceania; countries with economies in transition (Eastern Europe, Russia).

A great number of scientists (Holden \& Naydzhel, 2005; Doroshenko, 2012; Bukhonova, 2009; Shchetinina, 2013; Troshin, 2014) assume that in the heart of the world economic community there are highly developed industrial states playing a leading role in the application of high technology, scientific discovery, with a powerful military-industrial complex. Within this core multidirectional processes of cooperation and competition take place constantly. In turn according to the territorial principle among these countries are the North American block (United States, Canada), the Western European (EU), the Asian bloc (Japan, Singapore, Taiwan, South Korea). To our mind this classic concept of separation can be visually similar to the solar system, where the Sun as the center of attraction will be the industrialized countries, while the remaining will serve as planets and satellites. Thus, the kernel is the center of the latest technology and cutting-edge scientific ideas that will be the basis for the attraction of surrounding planets, servants, above all, the sources of supply of resources. So, providing raw materials and human material, third world countries will implement an infinite dependent rotation around the core of highly developed states.

\section{Method}

Methodology is based on the combination of the typical scientific approaches of the study of contemporary social-economic problem. In particular widely adapted method of describing the processes with the use of historical comparisons, by means of material-dialectical analysis. In the course of a study were used the diverse variants of the combination of the scientific tools of knowledge, namely analysis, synthesis, comparison, the systematization, classification, generalization. Generally the methodology is based on the acknowledgement theory and principals of complex and systematic approach to the study of procedures and phenomena in contemporary global economic life. Empirical base is built on the basis of the data of official statistics, facts of periodicals and results of personal studies of the author. 


\section{Results}

However, the system has undergone a qualitative change, and it is not least due to the rapid development of a group of countries, united by the acronym BRICS (Brazil, Russia, India, China, South Africa). The term BRICS was voiced by the chief economist of the bank Goldman Sachs Jim O'Nill in 2001 (Haq, 2007). In addition, the BRICS - global economic integration is the most active of the developing world, with its own resources for development and potential prospects of further economic growth. On the opinion of international experts, due to the rise of the BRICS economies will largely be the future world economic growth through the development of the real sector, strengthen financial sustainability and social stability.

This is confirmed by the figures:

- Now Brazil, Russia, India, China and South Africa are home to $43.0 \%$ of the population of the globe. BRICS countries are located in the four corners of the globe, they accounted for $30 \%$ of the land and 45 per cent of the total labour force in the world.

- The economies of the BRICS are most actively developing in the world. The BRICS countries' share of world GDP has increased from $14.6 \%$ in 2000 to 28 percent in 2014, and continues to rapidly grow. In 2000-2014, they secured a $55 \%$ growth in the global economy.

- According to experts, to 2050, the economies of the BRICS group will exceed the total size of the economies of the richest countries of the world (G-7) (Stolyarova, 2014, pp. 14-23).

In June 2010, an interdepartmental working group of member countries of the BRICS tentatively agreed on a draft long-term program of investment cooperation. The main principles of the project have been listed as the formation of the Interstate Fund for investment; orientation of joint projects to meet the demand of specific goods or services; use of national currencies in mutual settlements; adjustment of foreign trade legislation.

BRICS investment projects are directed towards large-scale sectored distribution of energy, forestry, processing of agricultural commodities, exploration, resource use and energy-saving technologies. "The BRICS countries, except Russia, survived the crisis relatively painless. High growth of industry, stable internal and external demand, the attractiveness of the investments into the economy are key characteristics of these countries", said Ilya Mitrofanov, head of the Analytical Department of the Invest found (Report of the meeting of the Government of the Russian Federation Ministry of industry "Innovation and introduction in manufacture of high technologies in Russian Federation”, 2013).

However, the structure of the BRICS is not even. Thus China and India mean more diversified economies showed significantly more confident economic growth than Brazil and Russia. China and India are developing states due to the growth in domestic consumer demand and public investment, so they are two countries with export-oriented commodity economy. Brazil economy is more diversified than the economy of Russia, because Russia's economy largely determines in the export of gas, oil, metals and fertilizer, and in Brazil, in addition to a strong resource base, there are more developed financial sector, agriculture, manufacturing and services. So we can expect negative manifestations in the export component of Brazil and Russia if world demand will continue its downward trend, coupled with the failure of leading central banks around the world (Kolomiec et al., 2011).

The most optimistic prospects are for China's economy, due to the total EU crisis. Domestically, such predictions are backed up by expanding domestic demand and competitiveness of Chinese goods. All this will push up prices for energy and commodities. Thus, the growing economies of China, driving demand for oil, gas and metals, will pull the country with enormous raw material base. At first glance, this is a definite advantage for the economy of Russia, however, remaining in the long-term the exporter of raw materials. So, the total exports of metal products, machinery, equipment, vehicles, food and manufactured goods is barely 30 percent, while the export of raw materials (oil, gas, wood) is over 70\%. It means not only the inefficiency of the country's natural resources, but also the threat to the safety for domestic producers (Stolyarova, 2014).

\section{Discussion}

The overall picture of geopolitical changes necessarily gives rise to thoughts about the persistent need structural transformations in the economy of Russia. The urgent shift is in emphasis with the extensive path of development, the active development of natural resources to intensive through the introduction of new technologies and effective research-and-production activities. This involves the setting up a mechanism of science-production and increased attention to the competitiveness of scientific and research not only on the part of private investors, but also involves extensive public programs (Danilov, 2004).

The present stage of development of scientific and technological revolution is entirely subordinate to its achievements in the field of scientific research and development. Traditionally in developed countries research 
and development take more than $2 \%$ of GDP, and the cost of the largest transnational corporations range from 10 to $20 \%$ of their total costs. State regulation of research and development is carried out in the context of science, technology, economics and education and is a complex of administrative mechanism (Dedilova, 2011).

In this case a well- known concept of "Foresigth", resulting in 70-ies of the last century in developed countries should be mentioned. Its wide distribution in the 90 's was due to the changed conditions of development, globalization of the economy and science, growing international competition in the markets of high technology, the limited budgetary resources, the necessity of speeding up the network economy, etc.

Currently, "Foresight" refers to the process of the systematic establishment of new strategic research directions and technological advances that, in the long run, will seriously affect the country's economic and social development. The essence of the approach is that the state with the help of companies defines advanced technologies over the next 10-20 years; directions of cooperation between business and the state in creating competitive innovation; activities that allow to use the new features to improve product quality and quality of life, economic growth and international competitiveness of the country. Foresight program has contributed to Western European countries in the expansion of cooperation between the various actors of research and development, scientific and business community, the Administration and the general public. In general, "Foresight" helps to direct science to solve national problems, gives the possibility to deal with the broad research paradigms, and the application of its principles can have a significant impact on the position of the scientific sector in Russia (Sokolov, 2007).

Foresight comes from the fact that offensive "desirable" version of the future largely depends on actions taken today, so the choice is accompanied by the development of measures to ensure an optimal trajectory of innovation development. Foresight projects as central component include the prospects for the development of science and technology. Typically, these issues become the subject of not only scientists, but also politicians, businessmen, practitioners from different sectors of the economy. The result of such discussions is the emergence of new ideas connected with the improvement of the mechanisms for the management of science, integrating science, education and industry and, ultimately, increase the competitiveness of the country, industry or region. In addition, the organization of systematic attempts to "look ahead" results in an enhanced culture of management and, consequently, to a more sound science, technology and innovation policy.

Foresight projects are aimed not only at gaining new knowledge in the form of reports, set of scenarios, recommendations they provide the development of informal relationships between their parties, the establishment of a unified picture of the situation. In some projects, we can see the formation of horizontal networks, areas in which scientists and businessmen, academics and Government officials, specialists from related fields can discuss common problems. Foresight is organized as a systematic process that must be carefully planned and organized. Typically, projects are being implemented fairly regularly, sometimes on a recurring pattern (similar to Japan's long-term forecast, which is conducted every 5 years, starting with 1971 years), in other cases, research is conducted as a series of interrelated projects aimed at addressing the complex interrelated problems and forming a consistent view on the long-term prospects of the technology, innovation and society (Doroshenko et al., 2013).

Foresight is much more comprehensive approach than traditional prediction. Predictions are usually formed by a narrow circle of experts and in most cases are associated with predictions lightly managed events (stock prices, weather forecasts, sports scores, etc.). In particular Foresight means the assessment of possible perspectives of innovation development, associated with the progress of science and technology, outlines possible technological horizons that can be achieved when attaching certain funds and the organization of systematic work, as well as the likely effects on the economy and society. Foresight always involves (often by intensive mutual discussions) many experts from all fields of activity, to one degree or another, related to the themes of the project, and sometimes conduct surveys of specific groups of population (inhabitants of the region, young people, etc.), directly involved in touching the problems discussed in the framework of the project. Moreover Foresight focuses on developing practical measures to bring the selected strategic guidance. Innovation in the West is being driven by competition for markets and is attractive for investors of tax exemption policies. Therefore in Russia it is important to warm up investment interest in innovation by businesses than just pour funds into the development of science (Osmova \& Boychenko, 2006).

One such initiative is the proposal of the Russian Chamber of Commerce to direct action, which would require all businesses to a certain percentage of their income to the Fund for modernization and technological development of the country. It is noteworthy that the amount of the deduction will be reduced in the size 
proportional to the cost of the campaign on its own innovation, including complex scientific research and experimental designing works (Glagolev, 2013).

Naturally one innovation stimulation is not enough to throw the Russian economy from the primary path of development. It is important to use innovative products. The first condition is to increase the competitiveness of domestic developments, because economic measures of protectionist policies of the state are not enough. Moreover artificial protection of domestic producers from foreign competition, contributes to a growing backlog in terms of creating new technologies. Another issue relates to the direct exploitation of research and development (Early \& Gibson, 2002). In this connection there is a need for an organization that, with the direct participation of the developers will conduct scientific and technical and legal expertise, market research, financial and economic calculations and solve organizational issues in the preparation and implementation of investment projects related to the introduction of high technologies.

A positive step forward in the development of innovative activities in Russia are the attempts to create a so-called science cities. So, on March 19, 2010, it was announced the formation of the scientific-technological complex on the development and commercialization of new technologies in Skolkovo, a sort of counterpart to the American Silicon Valley. The essential difference between a foreign prototype is the remoteness of the designed object from existing research centers, making it necessary to build expensive infrastructure mechanism. In contrast, Silicon Valley was established in the main scientific outposts of the Western United States. All the above leads to the conclusion that the essential problems of competitiveness, research and development, in our country are serious barriers to the introduction of their results into productive activities, both domestic and foreign enterprises (Zaitseva, 2011)

In terms of transnational corporations, science and research and development are in essence the technical preparation of production, which is economically justified to ensure the excellence of production through the introduction and development of new products, new technology and intensification of production processes.

Technical preparation of production covers all stages of research and development, and comprises a number of artworks:

1. Analysis, organization and information processing related technical development enterprise.

2. The design and implementation of scientific-research and experimental-designing works.

3. Research and development of new types of raw materials, ingredients.

4. Improvement of technological processes.

5. Designing new and further development of previously developed products with all necessary documentation.

6. The development of technical standards that are needed to calculate the intensity of production.

The efficient competitiveness management of scientific development is inseparably linked with the creation of the organizational structure of the corporation. The activities aiming to enhance the competitiveness of scientific research management is complicated because of institutional imperfection of disunity and divisions, duplication of functions, as well as the inadequacy of the structures to changing the purposes, objectives, themes. The most common shortcoming of traditional organizational structures of competitiveness management is their focus mainly on the stage of production. Thus there is a need for a specialized body responsible for delivering comprehensive work on improving the competitiveness of future products in the scientific and technological communities and transnational corporations.

It means the creating of a single control center for competitiveness, which is a coordinating nucleus, connecting all previously disparate services and departments for quality management and competitiveness. The most common concern of central management of competitiveness is the management, monitoring, coordination and planning of the competitiveness of future products. Nowadays the issue has not become the object of targeted research. Meanwhile the practice also showed the vital need of detailed study and consideration of this aspect in the initial stage of formation of product competitiveness. Emphasing primarily the stage of designing and researching works it is possible to survey the implication of the tasks mandated at the stage of production, implementation and operation. So an integrated approach in the management of competitivenes will take place. All the benefits achieved by such reformation of the organizational structure of research and development management, create in turn the framework for the new business units and the ability to integrate all the functions in single economic center of competitiveness management as a special department of transnational corporations.

The long-term development of science and technology cannot be provided only by extensive (quantitative) factors, in view of their limits (investment, growth in the number of academic institutions and professionals). 
(Mishchenko \& Stolyarova, 2010, pp. 68-71). In this case we can see the notorious law of transition from quantity to quality, from extensive to intensive development path. In order for new knowledge can be used in the production process, it is necessary to implement a range of research and technological development, the introduction of new techniques and technologies in the industry. The applied research, to promote the implementation of scientific ideas in production are the productive force of the society.

The beginning of the new Millennium was marked by scientific and technological advances, transformation of foundations of the world civilization. Effective research becomes the determining factor in the sustainable development of any country, enhancing its competitiveness in the world. The availability of advanced technologies is a major competitive advantage and a crucial aspect of the geopolitical balance of power. Leadership in the competitive struggle can only be achieved on a powerful scientific-technical basis, accumulating in the latest scientific advances, the combined expertise of academics, effective organization and management of research and development. Therefore, the position of the domestic economy is largely dependent on whether the State and society while preserving the richest scientific positions of the past to build a new forward base that provides a continuous flow of scientific ideas and their direction on a path of increasing production efficiency and well-being of the nation. Trends of economic life in the modern world are recognizing the effectiveness of the innovative model of economy.

Innovation economics can be characterized by the following signs:

- High level of development of education and science;

- Competitive quality of life;

- High index of economic freedom;

- Effective substitution of capital;

- Initiation of new markets;

- A wide variety of markets;

- A large proportion of innovative enterprises (over 60-80\%)

- Quality of human capital in its broadest sense.

\section{Conclusions}

Thus, there is a clear link between science in the broadest sense as the scope of research activities to the production of new knowledge of nature, society and research and development, which reflect and include all aspects of production: scientists with their knowledge and abilities qualifications and experience; scientific institutions; experimental and laboratory equipment; methods of scientific research; conceptual and categorical apparatus; system of scientific information, as well as the full amount of the cash advance knowledge, as a prerequisite, either, or the result of scientific production. Science and production is a single loop covering all processes from the appearance, development and elaboration of the idea to its realization in new product. Therefore, it makes sense to speak of a single system of "science-technology-production".

The immediate task of research works is to create new products that will be the basis of the production activity of the company in the future. Global scientific activity is the foundation and prerequisite for qualitative growth of the economy and the key to the prosperity of the nation. Research and development should be taken into account, of course, manufacturing and cultural traditions, organization, infrastructure, technological level of industry and national economy. The area of research works corresponds first to all activities in the future. Therefore it requires extremely fine management strategy, since all of the costs of research and development is an investment in the future of the company or the industry as a whole. The correctness of the chosen strategy can be assessed only after the realization of the finished product. Thus, research and development, characterized by the manipulation of the virtual potential competitiveness requires significant financial investments with varying degrees of risk.

\section{References}

Bukhonova, S. M., Doroshenko, Y. A., Slabinskaya, I. A., \& Chikina, E. D. (2009). Estimation and management of sustainable enetrprise development. Saint-Petersburg: Khimizdat.

Chizhova, E. N. (2004). Assessment of the financial capacity of the rationalization of the enterprise. Russian business, 3(51), 59-62.

Cupriyanov, S. V., Stolyarova, V. A., \& Stolyarova, Z. V. (2008). Management of research and development on product competitiveness. Belgorod: Belgorod State Technological University. 
Danilov, I. (2004). Innovation as a universal tool for enhancing the competitiveness of enterprises. Standards and quality, 1, 10-11.

Dedilova, T. V. (2011). Innovative activity as a characteristic feature of economic globalization. The global economy (pp. 228-237). Belgorod: Publishing and printing complex in NRU "BelSU".

Doroshenko, Yu. A., Bukhonova, S. M., Shchetinina, C. D., \& Stryabkova E. A. (2012). Features of development of social-economic systems in the context of globalization. Belgorod: Belgorod State Technological University.

Doroshenko, Yu. A., Somina, I. V., \& Komissarov, S. A. (2013). Sources of Financing and Innovative and Investment Activity of Small Enterprises. World Applied Sciences Journal, 25(6), 975-982. http://dx.doi.org/10.5829/idosi.wasj.2013.25.06.7071

Doroshenko, Yu. A., Taburchak, A. P., \& Gogua, L. S. (2013). Financial Management of High-Technology Innovation Enterprises. Middle-East Journal of Scientific Research, 17(9), 1327-1336. http://dx.doi.org/10.5829/idosi.mejsr.2013.17.09.7097

Early, P. C., \& Gibson, C. B. (2002). Multicultural work teams: a new perspective (pp. 102-104). New Jersey: Lawrence Erlbaum Assosiates.

Glagolev, S. N., \& Vaganova, O. V. (2013). Specific Determinants for structuring the Economy, Taking into Account the Factor of Integration. World Applied Sciences Journal, 24(10), 1322-1329. http://dx.doi.org/10.5829/idosi.wasj.2013.24.10.7008

Haq, M. (2007). The Human Development-Paradigm. In Readings in Human Development, Concepts, Measures and Policies for a Development Paradigm (pp. 44-47). New Delhi: Oxford University Press.

Holden, N. J. (2005). Crosscountry race- cultural management. Concept of cognitive management; Trans. with the Engl. Edited by. Prof. B. L. Eremina. - YUNITI- IT IS GIVEN.

Kolomiec, A. N., Gouzenkov, Y. G., \& Didorchuk, I. L. (2011). Uncertainty as a characteristic feature of the global economic system. In The global economy (pp. 188-204). Belgorod: Publishing and printing complex in NRU "BelSU".

Mishchenko, A. A., \& Stolyarova, V. A. (2010). Reforming the system of enterprise management based on its innovative approach. Belgorod: Belgorod State Technological University.

Osmova, M. N., \& Boychenko, A. V. (2006). The globalization of the world economy. Moscow: Infra-M.

Report of the meeting of the Government of the Russian Federation Ministry of industry "Innovation and introduction in manufacture of high technologies Russian " of 20.02.13. Moscow.

Rudychev, A. A. (1998). Competitiveness on building materials market. Saint-Petersburg: Khimizdat.

Shchetinina, C., Starikova, M., Ponomareva, T., \& Tumanov, S. (2013). Peculiarity of Market Positioning of the Food Industry in Russia. Middle-East Journal of Scientific Research, 17(8), 1138-1148. http://dx.doi.org/ 10.5829/idosi.mejsr.2013.17.08.7089.

Sokolov, A. (2007). Foresight: regard to future. Journal "Foresight", 1, 56-69.

Stolyarova, Z. (2014). Management of research and development works in the growing influence of transnational corporations. Belgorod: Belgorod State Technological University.

Troshin, A. S., Sandu, I. S., Kupriyanov, S. V., Stryabkova, E. A., \& Saldanha, H. F. D. (2014). Role and place of economic mechanism in modern conditions. Life Science Journal, 11(10s), 487-490. http://dx.doi.org/ 10.7537/j.issn.1097-8135.

Vechkanov, G. S. (2005). Economical security (pp. 256-302). Moscow: Vector.

Zaitseva, N. P. (2011). Modern trends in the global economy. In The global economy (pp. 150-158). Belgorod: Publishing and printing complex in NRU "BelSU".

\section{Copyrights}

Copyright for this article is retained by the author(s), with first publication rights granted to the journal.

This is an open-access article distributed under the terms and conditions of the Creative Commons Attribution license (http://creativecommons.org/licenses/by/3.0/). 